\title{
Contribution of Wintergreen Leaves to Early Spring Growth in the Wood Fern Dryopteris intermedia
}

\author{
JOSH VAN BUSKIRK* AND JOAN EDWARDS \\ Department of Biology, Williams College, Williamstown, MA 01267
}

In the thirty years since Monk's (1966) paper on the adaptive significance of evergreenness, several studies have compared evergreen with deciduous plants in order to explain their patterns of seasonal activity and geographic distribution (Chapin et al., 1980; Shaver and Chapin, 1980; Wagner, 1981; Gray, 1983). A number of advantages and disadvantages associated with the two leaf forms in particular environments have been identified, typically related to a trade-off between the costs of leaf construction and maintenance and the efficiency of photosynthesis (Chabot and Hicks 1982, Sobrado 1991). Few studies have experimentally measured the contribution to growth of retaining evergreen leaves for individuals of a single species. Here, we show that possession of leaves from the previous growing season confers a significant growth advantage on fiddleheads of the wintergreen wood fern, Dryopteris intermedia (Muhl.) A. Gray.

\section{METHODS}

The experiment was performed during the spring of 1982 in Williamstown, Berkshire County, Massachusetts. The study site was located in a mixed stand of Betula papyrifera and Acer rubrum at an elevation of $320 \mathrm{~m}$. We selected 30 pairs of Dryopteris intermedia on the basis of proximity and similarity in size and number of fronds. Members of a pair were within $3 \mathrm{~m}$ of one another.

On 1 April, before new growth began, we removed all wintergreen leaves from one randomly-chosen member of each pair; the other was left untouched. On 5- or 6-day intervals from 29 April to 25 May, we harvested and weighed (wet and dry weights) all new growth above the rhizome from five randomlyselected pairs. Herbivory on growing fiddleheads prevented 5 pairs of plants from being collected, reducing the sample size on three of the six collection dates.

\section{RESUlts}

Plants with intact wintergreen leaves grew more rapidly than those with leaves removed (Fig. 1). The initial weight of new growth in the two treatments was similar, but by late May the plants with intact fronds had grown to nearly twice the size of plants with fronds removed. There was some indication that

\footnotetext{
* Present address: J. Van Buskirk, Department of Biological Sciences, Texas Tech University, Lubbock, TX 79409-3131.
} 


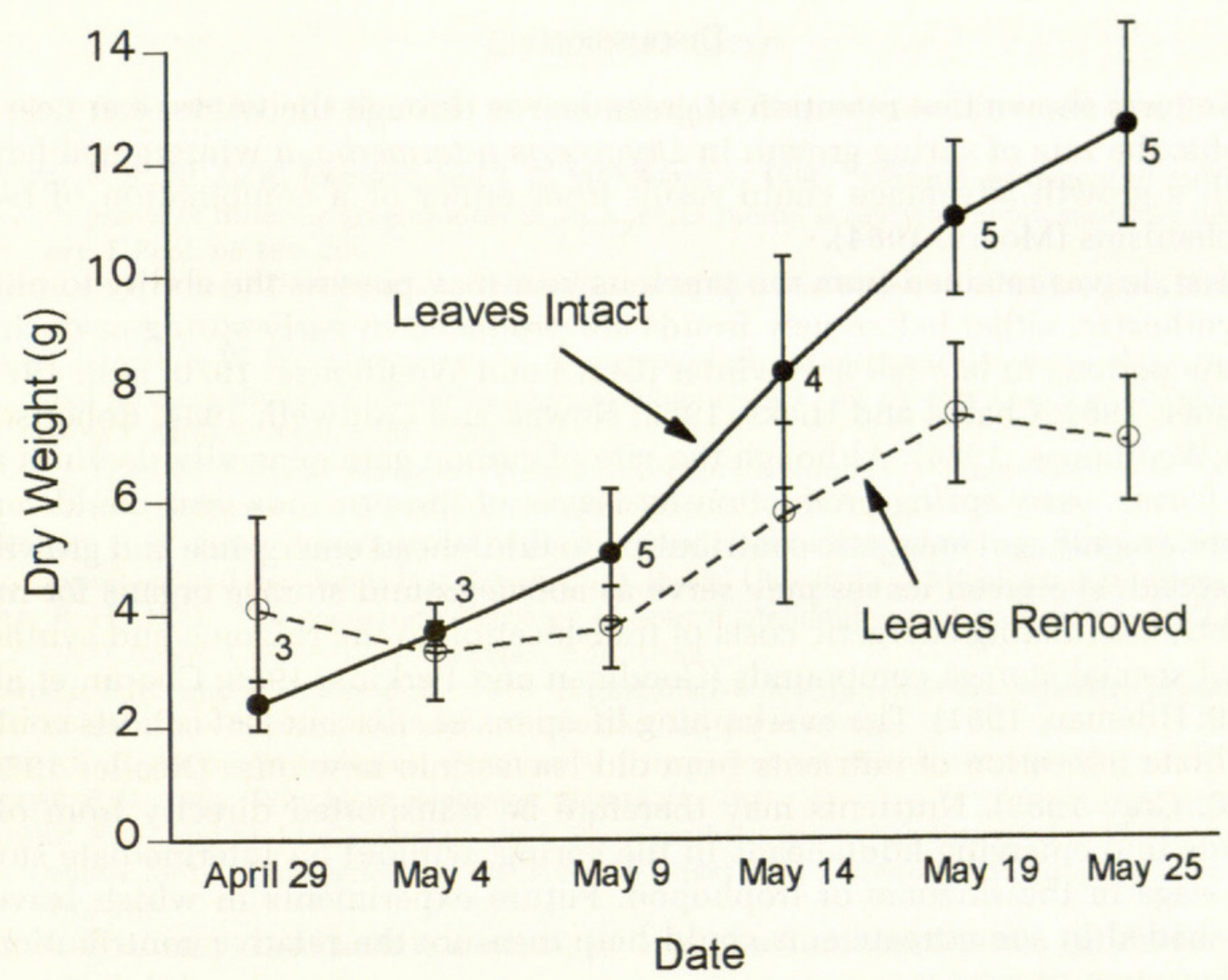

FIG. 1. Dryopteris intermedia plants from which wintergreen fronds were removed grew only 40 percent as rapidly in the early spring as did plants with intact fronds. Vertical bars show \pm 1 standard error of the mean, and the number of pairs collected on each sampling date is indicated. Initial weights were not equal to zero due to a small amount of growth before the first sample was collected, as well as the presence of leaf buds produced during the previous growth season.

weight-gain by new fiddleheads began about 10 days earlier in the plants with intact leaves (Fig. 1).

Analysis of covariance on the log-transformed dry weights of the growing fiddleheads included a significant date-by-treatment interaction $\left(\mathrm{F}_{1,46}=4.89\right.$, $\mathrm{P}=0.0320$ ), demonstrating that the presence of wintergreen leaves affected growth rate. The main effect of date was highly significant $\left(F_{1,46}=54.01\right.$, $\mathrm{P}=0.0001)$, reflecting the obvious growth of fiddleheads through time. The non-significant effect of the leaf removal treatment $(\mathrm{P}=0.6683)$ indicates that there was no overall weight difference between treatments, because the two treatments were different late in the experiment, but not in the initial samples.

The average growth rate of plants within the leaf-removal treatment was 60 percent less than that of control plants $(0.17 \mathrm{~g}$ dry weight/day versus 0.43 $\mathrm{g} /$ day in the control, $\left.\mathrm{F}_{1,8}=14.2, \mathrm{P}<0.005\right)$. Results for wet weight were similar. As suggested by Fig. 1, growth was not completed by 25 May, so we were unable to compare the final weights of control and experimental plants. 


\section{Discussion}

We have shown that retention of green leaves through the winter can nearly double the rate of spring growth in Dryopteris intermedia, a wintergreen fern. Such a growth advantage could result from either or a combination of two mechanisms (Moore, 1984).

First, leaves retained from the previous year may possess the ability to photosynthesize, either before new fronds are produced in early spring or during sunny periods in late fall and winter (Grace and Woolhouse, 1970; Hill, 1971; Wagner, 1981; Chabot and Hicks, 1982; Nowak and Caldwell, 1984; Robertson and Woolhouse, 1984). Although the rate of carbon gain generally declines in old leaves, early spring production by leaves of the previous year could represent a significant energetic contribution to fiddlehead emergence and growth.

Second, evergreen leaves may serve as above-ground storage organs for nutrients, eliminating energetic costs of translocation to the rhizome and synthesis of special storage compounds (Goodman and Perkins, 1959; Chapin et al., 1980; Hileman, 1981). The overlapping lifespans of adjacent leaf cohorts could facilitate relocation of nutrients from old leaves into new ones (Reader 1978, 1980, Gray 1983). Nutrients may therefore be transported directly from old fronds into emerging fiddleheads in the spring, without an intermediate storage stage in the rhizome or trophopod. Future experiments in which leaves are shaded in some treatments could help measure the relative contributions of these two processes.

Leaf growth form may influence altitudinal distributions of Dryopteris ferns in New England. Mahall and Bormann (1978) found that high elevation populations of $D$. intermedia in New Hampshire experience a greater frequency of over-winter leaf breakage than did nearby low elevation populations. Ferns at high elevations are exposed to colder temperatures than those at low elevations, and frost may be more likely to precede the arrival of a protective snow layer. Furthermore, $D$. intermedia is replaced at the highest elevations by a deciduous fern, D. campyloptera (Kunze) Clarkson (Mahall and Bormann, 1978; Ogden, 1981). Perhaps a wintergreen growth form pays off only in habitats where leaves have a high probability of remaining attached to the rhizome through the winter. Our data show that loss of leaves through breakage at high elevation would reduce growth rate, perhaps making $D$. intermedia competitively inferior to deciduous species.

In summary, our results illustrate that enhanced early-season growth represents one advantage to developing an evergreen rather than deciduous growth form. For herbaceous plants, however, this advantage can only be realized in environments sufficiently moderate to ensure that leaves remain attached throughout the year.

\section{ACKNOWLEDGMENTS}

The Biology Department and Center for Environmental Studies at Williams College kindly provided facilities and equipment for this research. Thanks to D. R. Hileman, R. Relyea, D. C. Smith, and W. H. Wagner for comments on the manuscript and general advice. 


\section{Literature Cited}

Снавот, B. F., and D. J. Hicks. 1982. The ecology of leaf life spans. Ann. Rev. Ecol. Syst. 13:229260.

Chapin, F. S., III, D. A. Johnson, and J. D. McKendrick. 1980. Seasonal movement of nutrients in plants of differing growth form in an Alaskan tundra ecosystem: implications for herbivory. J. Ecol. 68:189-209.

GoOdman, H. J., and D. F. PERKINS. 1959. Mineral uptake and retention in cotton-grass (Eriophorum vaginatum L.). Nature 184:467-468.

GRACE, J., and H. W. WOOLhOUSE. 1970. A physiological and mathematical study of the growth and productivity of a Calluna-Sphagnum community. I. Net photosynthesis of Calluna vulgaris L. Hull. J. Appl. Ecol. 7:363-381.

GRAY, J. T. 1983. Nutrient use by evergreen and deciduous shrubs in southern California. I. Community nutrient cycling and nutrient use efficiency. J. Ecol. 71:21-41.

Hileman, D. R. 1981. A comparison of photosynthetic production, phenology, and herbivory in evergreen and deciduous bog shrubs. Ph.D. thesis, University of Michigan, Ann Arbor.

HiLl, R. H. 1971. The comparative ecology of several pteridophytes of southeastern Michigan. Ph.D. thesis, University of Michigan, Ann Arbor.

Mahall, B. E., and F. H. Bormann. 1978. A quantitative description of the vegetative phenology of herbs in a northern hardwood forest. Bot. Gaz. 139:467-481.

MONK, C. D. 1966. An ecological significance of evergreenness. Ecology 47:504-505.

MOORE, P. D. 1984. Why be an evergreen. Nature 312:703.

NowAK, R. S., and M. M. CALDWELL. 1984. Photosynthetic activity and survival of foliage during winter for two bunchgrass species in a cold-winter steppe environment. Photosynthetica 18: 192-200.

Ogden, E. C. 1981. Field guide to northeastern ferns. New York State Museum Bulletin No. 444: i-vi, 1-122.

READER, R. J. 1978. Contributions of over-wintering leaves to the growth of three broad-leaved, evergreen shrubs belonging to the Ericaceae family. Canad. J. Bot. 56:1248-1261.

- 1980. Effects of nitrogen fertilizer, shade, and the removal of new growth on longevity of over-wintering bog ericad leaves. Canad. J. Bot. 58:1737-1743.

ROBERTSON, K. P., and H. W. WoOlhouse. 1984. Studies of the seasonal course of carbon uptake of Eriophorum vaginatum in a moorland habitat. J. Ecol. 72:685-700.

SHAver, G. R., and F. S. CHAPIN III. 1980. Response to fertilization by various plant growth forms in an Alaskan tundra: nutrient accumulation and growth. Ecology 61:781-789.

Sobrado, M. A. 1991. Cost-benefit relationships in deciduous and evergreen leaves of tropical dry forest species. Funct. Ecol. 5:608-616.

WAGNER, H. B. 1981. Seasonality and leaf phenology: ecological and physiological patterns in Dryopteris ferns. Bull. Ecol. Soc. Amer. 62:161. [Abstract] 


\section{$2 \mathrm{BHL}$ Biodiversity Heritage Library}

Van Buskirk, Josh and Edwards, Joan E. 1995. "Contribution of Wintergreen Leaves to Early Spring Growth in the Wood Fern Dryopteris intermedia." American fern journal 85, 54-57. https://doi.org/10.2307/1547466.

View This Item Online: https://www.biodiversitylibrary.org/item/100484

DOI: https://doi.org/10.2307/1547466

Permalink: https://www.biodiversitylibrary.org/partpdf/230642

\section{Holding Institution}

Missouri Botanical Garden, Peter H. Raven Library

\section{Sponsored by}

Missouri Botanical Garden

\section{Copyright \& Reuse}

Copyright Status: In copyright. Digitized with the permission of the rights holder.

License: http://creativecommons.org/licenses/by-nc-sa/3.0/

Rights: https://biodiversitylibrary.org/permissions

This document was created from content at the Biodiversity Heritage Library, the world's largest open access digital library for biodiversity literature and archives. Visit BHL at https://www.biodiversitylibrary.org. 